\title{
Use of hormonal subdoses applied in Bai Hui acupuncture in estrus synchronization protocols for goats
}

\author{
Uso de subdoses hormonais aplicadas no acuponto Bai Hui em \\ protocolos de sincronização de estro para cabras
}

\author{
Diego Oliveira de Souza ${ }^{1}$; Monna Lopes de Araujo ${ }^{1}$; Carmo Emanuel Almeida \\ Biscarde $^{2}$; Claudinéia Silva Mendes ${ }^{1}$; Mariana Alves de Andrade Silva ${ }^{1}$; Diana \\ Carolina Moya Romero ${ }^{1}$; Bianor Matias Cardoso Neto후 Ana Lúcia Almeida \\ Santana ${ }^{3}$; Larissa Pires Barbosa ${ }^{4 *}$
}

\begin{abstract}
The objective of this study was to evaluate the efficacy of delivering reduced doses of hormones via the Bai Hui acupoint in estrus synchronization in goats. A total of 40 goats received intravaginal sponges with medroxyprogesterone acetate for 7 days. The goats were then randomly distributed into 5 treatment: T1 - application of $132.5 \mu \mathrm{g}$ of cloprostenol and $300 \mathrm{IU}$ of equine chorionic gonadotropin (eCG), both by intramuscular injection (IM); T2 - application of $39.75 \mu \mathrm{g}$ cloprostenol at the Bai Hui acupoint, and $300 \mathrm{IU}$ of eCG by IM; T3 - application of $132.5 \mu \mathrm{g}$ of cloprostenol by IM, and $90 \mathrm{IU}$ of eCG at the Bai Hui acupoint; T4 - application of 39.75 $\mu$ g of cloprostenol and 90 UI of eCG, both in Bai Hui and T5 acupuncture: application of $39.75 \mu \mathrm{g}$ of cloprostenol and $90 \mathrm{UI}$ of eCG, both applied in false acupoint. The goats were subjected to an estrus synchronization protocol and monitored for estrus detection, coverage and evaluation of reproductive parameters to detect entry into estrus. The data were subjected to normality tests, followed by appropriate statistical analyses of each variable. There was no significant difference $(\mathrm{P}>0.05)$ in the percentage of animals in estrus $(95.00 \pm 11.18 \%)$, interval between sponge removal and beginning of estrus $(49.72 \pm 8.93 \mathrm{~h})$, interval between sponge removal and end of estrus $(76.84 \pm 11.98 \mathrm{~h})$, duration of estrus $(27.08 \pm 8.68 \mathrm{~h})$, size of the largest follicle (6.82 \pm $0.44 \mathrm{~mm}$ ), interval between sponge removal and ovulation $(78.28 \pm 10.82 \mathrm{~h})$, time from ovarian onset to estrus $(28.52 \pm 5.44 \mathrm{~h})$, follicular growth rate $(0.86 \pm 0.29 \mathrm{~mm} /$ day $)$, number of ovulations $(1.32 \pm 0.23)$, plasma progesterone concentration at 7 days after ovulation $\left(10.28 \pm 1.65 \mathrm{ng} \cdot \mathrm{mL}^{-1}\right)$, and gestation rate at 30 days after the beginning of estrus $(75 \pm 12.5 \%)$. However, the cost of the synchronization protocol per animal was $43.42 \%$ lower in treatments 4 and 5 (30\% of the doses) than in treatment $1(100 \%$ of the dose). Ovulation and estrus were efficiently synchronized with the use of $39.75 \mu \mathrm{g}$ of sodium cloprostenol and $90 \mathrm{UI}$ of eCG, applied at the Bai Hui acupoint or at a false acupoint.
\end{abstract}

Key words: Acupuncture. Caprinocultura. Reproductive behavior. Estro.

\footnotetext{
1 Discentes, Universidade Federal do Recôncavo da Bahia, UFRB, Cruz das Almas, BA, Brasil. E-mail: pantaneiro.diego@gmail. com; monnalopes@hotmail.com; caumendes18@gmail.com; marianadeandradesilva@gmail.com; carolinitamoya@gmail.com; bianorneto@gmail.com

2 Pesquisador, Universidade Federal do Recôncavo da Bahia, UFRB, Cruz das Almas, BA, Brasil. E-mail: carmoemanuel@gmail. com

3 Discente, Universidade Federal de Viçosa, UFV, Viçosa, MG, Brasil. E-mail: ninhaemarc@hotmail.com

${ }^{4}$ Prof $^{a}$, Universidade Federal do Recôncavo da Bahia, UFRB, Cruz das Almas, BA, Brasil. E-mail: larissa@ufrb.edu.br

* Author for correspondence
} 


\section{Resumo}

O objetivo com o estudo foi avaliar a utilização de subdoses hormonais aplicadas no acuponto Bai Hui em protocolos de sincronização de estro em cabras. Foram utilizadas 40 cabras, as quais receberam esponjas intravaginais com acetato de medroxiprogesterona durante 7 dias, quando foram distribuídas aleatoriamente em 5 tratamentos: T1: aplicação de 132,5 $\mu \mathrm{g}$ de cloprostenol e 300UI de eCG, ambos por

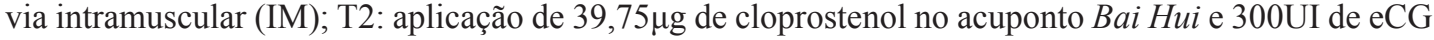
IM; T3: aplicação de 132,5 $\mu$ de cloprostenol IM e 90UI de eCG no acuponto Bai Hui; T4: aplicação

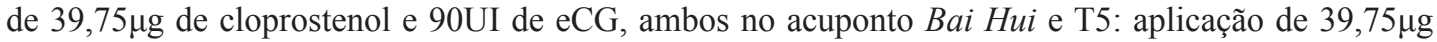
de cloprostenol e 90UI de eCG, ambos aplicados em falso acuponto. As cabras foram submetidas à protocolo de sincronização de estro e monitoradas para detecção de estro, realização das coberturas e avaliação dos parâmetros reprodutivos. Os dados foram submetidos à análise de normalidade, seguido dos testes estatísticos adequados para cada variável. Não obteve-se diferença $(p>0,05)$ para porcentagem de animais em estro $(95,00 \pm 11,18 \%)$, intervalo da retirada da esponja ao início do estro $(49,72 \pm 8,93 \mathrm{~h})$, intervalo da retirada da esponja ao final do estro $(76,84 \pm 11,98 \mathrm{~h})$, duração do estro $(27,08 \pm 8,68 \mathrm{~h})$, tamanho do maior folículo $(6,82 \pm 0,44 \mathrm{~mm})$, intervalo da retirada da esponja à ovulação $(78,28 \pm 10,82 \mathrm{~h})$, intervalo do início do estro à ovulação $(28,52 \pm 5,44 \mathrm{~h})$, taxa de crescimento folicular $(0,86 \pm 0,29 \mathrm{~mm} / \mathrm{dia})$, número de ovulações $(1,32 \pm 0,23)$, concentração de progesterona plasmática aos 7 dias após ovulação $\left(10,28 \pm 1,65 \mathrm{ng} \cdot \mathrm{mL}^{-1}\right)$ e para taxa de gestação aos 30 dias $(75 \pm 12,5 \%)$. Porém, o custo do protocolo de sincronização por animal foi 43,42\% menor para os tratamentos T4 e T5 (30\% da dose) comparado com o T1 (100\% da dose). A ovulação e o estro foram eficientemente sincronizados

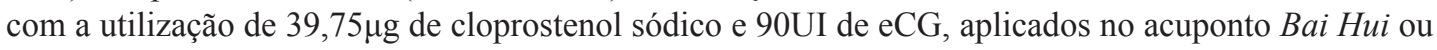
em falso acuponto.

Palavras-chave: Acupuntura. Caprinocultura. Comportamento reprodutivo. Estro.

\section{Introduction}

Goat raising, similar to other segments of Brazilian agribusiness, requires investment in technological advancements that improve productivity (TEIXEIRA et al., 2013). Such advancements include reproductive biotechniques such as estrus and ovulation synchronization, as well as genetic improvements (BALDASSARE, 2007). The use of reproductive biotechnology reduces production costs, since it allows rationalized animal management (URIBE-VELÁSQUEZ et al., 2010).

The most common methods for estrus induction and synchronization, and follicular growth stimulation in goats involve administration of progesterone, equine chorionic gonadotropin (eCG), and Prostaglandin F2 $\alpha$ (PGF2 $\alpha$ ). These hormones are most commonly administered by intramuscular injection. However, other routes of administration have been tested, including injection into the Bai Hui (MARTINEZ et al., 2007; ARAÚJO, 2016),
Hou Hai (ARAÚJO, 2016; CARDOSO et al., 2018), B22 and B23 (KÜÇÜKASLAN et al., 2015) acupoints.

The Bai Hui (which means "One Hundred Meetings") acupoint is located in the lumbosacral space, between the spinal process of the last lumbar vertebra and the first sacral vertebra (MARTINEZ et al., 2007), and is already used in pharmacopuncture, in which reduced doses of various drugs are injected into an acupoint. According to Altman (2006), the acupoint is stimulated via pressure created by presence of the drug when it is deposited in the local subcutaneous tissue, potentiating the drug's pharmacological effect. Other studies have sought to define minimal effective doses when hormones are administrated by different routes in the goat estrus synchronization protocols (FONSECA et al., 2005; ARAÚJO, 2016; CARDOSO et al., 2018) and according to Luna et al. (2006) the injection of reduced doses into acupoints produces effects 
of similar strength and duration to those produced by the conventional dose, while causing fewer side effects.

The objective of this study was to evaluate the efficacy of delivering reduced doses of hormones via the Bai Hui acupoint in estrus synchronization in goats.

\section{Material and Methods}

\section{Experiment location and trial period}

These studies were performed at the Riocon Farm, located in Manoel Vitorino-BA, between November 2011 and May 2012. Mean temperature and humidity as measured with a thermo-hygrometer (THAL - 300 Termo Higro Anemômetro Luxímetro Digital, Instrutherm ${ }^{\mathrm{TM}}$, São Paulo, Brasil) were 29.7 ${ }^{\circ} \mathrm{C}$ and $63.2 \%$, respectively. Follicular dynamics and estrus behavior data were collected daily at 10:00 AM and 4:00 PM.

\section{Animals and management}

A total of forty, 2-4-year-old goats were used. The goats used were the progeny of cross bred Anglo Nubiana and Boer parents, had body condition scores between 2.5 and 3.0, and a history of calving, with a lactation dry period of at least 60 days. Females were selected by clinical and gynecological examination using transrectal ultrasonography (Pie Medical ${ }^{\mathrm{TM}}$, modelo ÀquilaVet, linear transducer $6 \mathrm{MHz}$ ). The goats received Tifton hay and concentrated supplements based on alfalfa bran (Medicago sativa) and algaroba (Prosopis juliflora) twice a day, with mineral mix and water available ad libitum.

\section{Hormonal protocol and experimental distribution}

All goats received intravaginal sponges impregnated with $60 \mathrm{mg}$ of medroxyprogesterone acetate (MAP) (Progespon $^{\mathrm{TM}}$, Syntex, Buenos Aires, Argentina), and $0.1 \mathrm{mg}$ of oxytetracycline (Kuramicina $^{\mathrm{TM}}$, König do Brasil LTDA) each morning for a period of 7 days. Animals were then randomly distributed into 5 treatment (Table 1).

Table 1. Hormonal protocol and experimental distribution.

\begin{tabular}{ll}
\hline Treatment & Hormones and aplication route \\
\hline \multirow{2}{*}{ T1 $(\mathbf{n}=\mathbf{8})$} & D6 of protocol $=0.5 \mathrm{~mL}(132.5 \mu \mathrm{g})$ of cloprostenol \\
& D7 of protocol $=300 \mathrm{IU}$ of eCG $(1.5 \mathrm{~mL})$, both applied intramuscularly (IM) \\
T2 $(\mathbf{n}=\mathbf{8})$ & D6 of protocol $=0.15 \mathrm{~mL}(39.75 \mu \mathrm{g})$ of cloprostenol, in the Bai Hui acupoint \\
& D7 of protocol $=300 \mathrm{IU}$ of eCG $(1.5 \mathrm{~mL}), \mathrm{IM}$ \\
T3 $(\mathbf{n}=\mathbf{8})$ & D6 of protocol $=0.5 \mathrm{~mL}(132.5 \mu \mathrm{g})$ of cloprostenol IM \\
& D7 of protocol $=90 \mathrm{IU}$ of eCG $(0.45 \mathrm{~mL})$, in Bai Hui acupoint \\
T4 $(\mathbf{n}=\mathbf{8})$ & D6 of protocol $=0.15 \mathrm{~mL}(39.75 \mu \mathrm{g})$ of cloprostenol \\
& D7 of protocol $=90 \mathrm{IU}$ of eCG $(0.45 \mathrm{~mL})$, both applied in Bai Hui acupoint \\
T5 $(\mathbf{n}=\mathbf{8})$ & D6 of protocol $=0.15 \mathrm{~mL}(39.75 \mu \mathrm{g})$ of cloprostenol \\
& D7 of protocol $=90 \mathrm{IU}$ of eCG $(0.45 \mathrm{~mL})$, both applied in false acupoint
\end{tabular}

Prostaglandin (synthetic analogue cloprostenol sodium - Ciosin ${ }^{\mathrm{TM}}$, Coopers, Brazil); eCG = Equine Chorionic Gonadotrophin (Novormon, Coopers ${ }^{\mathrm{TM}}$, Brazil). It was defined as the false acupoint the intramuscular route (IM), performed in the hind limb with administration in the semitendinosus muscle, this place being standardized for all the animals that received the hormonal dose IM. 


\section{Pharmacopuncture protocol}

Before hormonal application, antisepsis of injection sites was performed with iodopovidone (PVPi) (Riodeine ${ }^{\mathrm{TM}}$, Rioquímica, São Paulo, Brazil). The Bai Hui acupoint is located between the last lumbar and first sacral vertebrae, and is identified by palpation. The needle is inserted above the medullary canal. For injection into this acupoint, $25 \times 7$ hypodermic needles were inserted at an angle of $90^{\circ}$ relative to the overlying skin.

For the false acupoint, intramuscular (IM) administration was performed in the semitendinosus muscle of the hind limb, this place being standardized for all the animals that received the hormonal dose IM.

\section{Evaluated variables and methodologies adopted}

The present study evaluated the percentage of animals in estrus (AE); the interval between sponge removal and beginning of estrus (IREIE); interval between sponge removal and end of estrus (IREFE); duration of estrus (DE); interval between sponge removal and ovulation; number of ovulations; follicular growth rate; diameter of the largest follicle; plasma progesterone level; gestation rate and prolificacy; and protocol cost.

After sponge removal and eCG application, the animals were checked every $12 \mathrm{~h}$ for estrus by exposure to breeding males, and andrologically evaluated. The moment at which a female accepted mounting was taken to be the beginning of estrus. The first time a female in estrus refused mounting was taken to be the end of estrus.

Folliculargrowth and ovulation evaluations began immediately after withdrawal of sponges, and was performed at $12 \mathrm{~h}$ intervals using ultrasonography. Evaluations ended $12 \mathrm{~h}$ after ovulation, which was verified by observing disappearance of the preovulatory follicle. Imaging of the ovaries was performed by transrectal ultrasound (Pie Medical ${ }^{\mathrm{TM}}$, model ÀquilaVet, coupled to a linear transducer of 6.0 and $8.0 \mathrm{MHz}$ ). Exams were performed by a single evaluator.

The interval between sponge withdrawal and ovulation was measured in hours. Ovulation time was taken to be the midpoint between the time of the last observation of the ovulatory follicle, and the time when the follicle was noted to have disappeared. The growth rate of the ovulatory follicle ( $\mathrm{mm} /$ day) was obtained by taking the difference between the final and initial diameters of the follicle, dividing by the number of intervening hours, and multiplying by 24 . Follicular diameter was represented by the greater length of the antral cavity.

To measure plasma progesterone concentrations, blood was collected from the jugular vein on the 7th day after ovulation using vacuum tubes, and centrifuged at $3000 \times \mathrm{g}$ for $15 \mathrm{~min}$ to obtain plasma. A commercial chemiluminescence kit was used to determine plasma progesterone concentrations (Access Progesterone, Beckman Coulter ${ }^{\mathrm{TM}}$ ). Assays were performed at the Federal University of Viçosa.

To determine gestation and prolificity rates, upon detection of estrus, the goats were submitted to natural mating at $12 \mathrm{~h}$ intervals. The number of coverings varied according to receptivity of each female. Pregnancy diagnosis was performed 30 days after coverage using a transrectal ultrasonograph (Pie Medical ${ }^{\mathrm{TM}}$, model ÀquilaVet) coupled to a 6.0 $\mathrm{MHz}$ linear transducer. Visualization of embryonic vesicles and heart beats was considered to be a positive diagnosis. After birthing, prolificity was determined by dividing the total number of live and dead kids by the number of births.

Market values of the hormones (Table 2) were used to determine the cost of each hormone in each treatment, as shown below:

$$
\text { Hormonal cost/protocol }=\frac{\text { Volume administered }(\mathrm{mL}) \text { X market value/bottle of hormone }}{\text { Total bottle volume }(\mathrm{mL})}
$$


Table 2. Cost per Hormonal, quoted in Cruz das Almas city, Bahia, Brazil, March 2012.

\begin{tabular}{cccc}
\hline Item & Sponge (25 units) & Prostaglandin F2 $\alpha(5 \mathrm{mg} / \mathbf{2 0 m L})$ & eCG (5.000IU/25mL) \\
\hline Cost US\$ & 88.75 & 33.14 & 82.84 \\
\hline
\end{tabular}

eCG- Equine Chorionic Gonadotrophin; US \$ - Dollar. The conversion from the Real to the Dollar was made considering the price of the Commercial Dollar, at the purchase price according to the quotation published by Banco do Brasil on its website <http: // cotacoes.agronegocios 48 e.com.br/investimentos/conteudoi.asp? option = dolar \& title =\% 20D\% F3lar>, on April $24,2013$.

\section{Statistical analysis}

Normality of data was evaluated using the Shapiro-Wilk test. Quantitative analyses of the variables that presented normal distributions were performed by ANOVA and Tukey's test with a significance threshold of 5\%. The non-parametric Chi-square test $\left(\chi^{2}\right)$ was adopted assessing the binomial qualitative variables (animals in estrus and gestation rate), with a significance threshold of $5 \%$.

\section{Results}

The differences in treatment regimens applied to each group of goats did not influence the percentage of goats in estrus, the interval between the removal of the sponge and the beginning of estrus, the interval between the removal of the sponge and the end of estrus, or the duration of estrus $(\mathrm{p}>0.05)$ (Table 3).

Table 3. Estrous behavior of goats submitted to synchronization protocols with hormonal application on Bai Hui acupoint.

\begin{tabular}{cccccc}
\hline Variables & T1 & T2 & T3 & T4 & T5 \\
\hline AE (\%) & $100(8 / 8)$ & $100(8 / 8)$ & $100(8 / 8)$ & $100(8 / 8)$ & $75(6 / 8)$ \\
IRIE (h) & $51.8 \pm 5.8$ & $49.8 \pm 0.4$ & $40.7 \pm 21.1$ & $63.4 \pm 23.2$ & $42.9 \pm 18.2$ \\
IRFE (h) & $78.8 \pm 15.1$ & $68.1 \pm 7.5$ & $80.7 \pm 19.3$ & $93.7 \pm 6.8$ & $62.9 \pm 16.4$ \\
DE (h) & $27.0 \pm 11.2$ & $18.3 \pm 7.9$ & $39.9 \pm 13.1$ & $30.2 \pm 17.3$ & $20.0 \pm 6.5$ \\
\hline
\end{tabular}

$\mathrm{AE}=$ animals in estrus; IRIE = interval between sponge removal and onset of estrus; IRFE = interval between sponge removal and end of estrus; $\mathrm{DE}=$ duration of estrus. $\mathrm{T} 1=100 \%$ of the eCG and intramuscular PGF $2 \alpha$ doses, $\mathrm{T} 2=100 \%$ of the eCG dose and $30 \%$ of the PGF $2 \alpha$ dose in the acupoint, T3 $=30 \%$ of the eCG dose in the acupoint and $100 \%$ of the intramuscular PGF $2 \alpha$ dose, T 4 $=30 \%$ of the dose of eCG and PGF $2 \alpha$ in the acupoint and T $5=30 \%$ of the dose of eCG and PGF $2 \alpha$ in the false acupoint. Data refer to average \pm standard deviation and there was no difference between treatments by means of variance at $5 \%$ probability analysis.

Follicular variables were not influenced $(\mathrm{p}>$ 0.05 ) by the protocols investigated in the present study (Table 4). The size of the largest follicle in each treatment group was similar, suggesting that reducing the recommended dose of eCG by $70 \%$ does not limit follicle development.
Gestation rates, induced progesterone levels, and prolificity were not influenced by the reduced dose treatments $(p>0.05)$ (Table 5), demonstrating that the reduced dosage of eCG (90 IU) yielded satisfactory responses for these variables in goats. 
Table 4. Follicular dynamics evaluated in goats submitted to estrus synchronization protocols with hormonal applications in the Bai Hui acupoint.

\begin{tabular}{cccccc}
\hline Variables & T1 & T2 & T3 & T4 & T5 \\
\hline TMF (cm) & $0.62 \pm 0.18$ & $0.68 \pm 0.20$ & $0.70 \pm 0.08$ & $0.67 \pm 0.02$ & $0.74 \pm 0.08$ \\
IREO (h) & $75.7 \pm 5.7$ & $73.6 \pm 0.4$ & $76.0 \pm 22.2$ & $97.0 \pm 11.0$ & $69.1 \pm 20.2$ \\
IIEO (h) & $23.9 \pm 0.1$ & $23.8 \pm 0.0$ & $35.2 \pm 11.4$ & $33.5 \pm 12.1$ & $26.2 \pm 5.2$ \\
TCF (mm/day) & $0.5 \pm 0.5$ & $0.9 \pm 0.7$ & $0.8 \pm 0.4$ & $0.8 \pm 0.4$ & $1.3 \pm 1.3$ \\
NO & $1.50 \pm 0.9$ & $1.12 \pm 0.9$ & $1.25 \pm 0.8$ & $1.62 \pm 0.9$ & $1.12 \pm 0.9$ \\
\hline
\end{tabular}

$\mathrm{TMF}=$ size of the largest follicle; IREO $=$ Interval batween withdrawal of sponge and ovulation; IIEO = interval from the beginning of estrus to ovulation; TCF $=$ follicular growth rate; $\mathrm{NO}=$ number of ovulations. T1 $=100 \%$ of the eCG and intramuscular PGF $2 \alpha$ doses, $\mathrm{T} 2=100 \%$ of the eCG dose and $30 \%$ of the PGF $2 \alpha$ dose in the acupoint, T3 $=30 \%$ of the eCG dose in the acupoint and $100 \%$ of the intramuscular PGF $2 \alpha$ dose, T $4=30 \%$ of the dose of eCG and PGF $2 \alpha$ in the acupoint and T5 $=30 \%$ of the dose of eCG and PGF $2 \alpha$ in the false acupoint. Data refer to average \pm standard deviation and there was no difference between treatments by means of variance at $5 \%$ probability analysis.

Table 5. Gestation rate, progesterone concentration and prolificacy of goats submitted to synchronization protocols with hormonal application in Bai Hui acupoint.

\begin{tabular}{cccccc}
\hline Variables & T1 & T2 & T3 & T4 & T5 \\
\hline Gestation rate (\%) & $87.5 \pm 0.3$ & $62.5 \pm 0.5$ & $75.0 \pm 0.4$ & $87.5 \pm 0.3$ & $62.5 \pm 0.5$ \\
Progesterone (ng.mL $\mathbf{m}^{-1}$ ) & $12.96 \pm 4.95$ & $9.66 \pm 5.49$ & $10.64 \pm 3.39$ & $9.38 \pm 5.33$ & $8.75 \pm 4.28$ \\
Prolificacy & $1.50 \pm 0.9$ & $1.12 \pm 0.9$ & $1.25 \pm 0.8$ & $1.62 \pm 0.9$ & $1.12 \pm 0.9$ \\
\hline
\end{tabular}

$\mathrm{TG}=30$ days gestation rate; $\mathrm{T} 1=100 \%$ of the eCG and intramuscular PGF $2 \alpha$ doses, $\mathrm{T} 2=100 \%$ of the eCG dose and $30 \%$ of the PGF $2 \alpha$ dose in the acupoint, T3 $=30 \%$ of the eCG dose in the acupoint and $100 \%$ of the intramuscular PGF $2 \alpha$ dose, T4 $=30 \%$ of the dose of eCG and PGF $2 \alpha$ in the acupoint and T5 $=30 \%$ of the dose of eCG and PGF $2 \alpha$ in the false acupoint. Data refer to average \pm standard deviation and there was no difference between treatments by means of variance at $5 \%$ probability analysis.

In the present study, we also evaluated each protocol's cost (Table 6). The protocols in which $30 \%$ of the recommended eCG dose was applied at the Bai Hui or false acupoint reduced cost by $43.42 \%$, but maintained the full efficacy of the standard protocol in which $100 \%$ of the recommended eCG dose was administered by intramuscular injection.

Table 6. Cost of the estrus synchronization protocol in goats with hormonal application in Bai Hui acupoint.

\begin{tabular}{lccccc}
\hline Variables & T1 & T2 & T3 & T4 & T5 \\
\hline Value/Animal(R\$) & 30.89 & 30.28 & 24.17 & 23.56 & 23.56 \\
Value/Product(R\$) & 20.59 & 26.91 & 19.33 & 14.49 & 20.59 \\
\hline
\end{tabular}

$\mathrm{T} 1=100 \%$ of the eCG and intramuscular PGF $2 \alpha$ doses, T2 $=100 \%$ of the eCG dose and $30 \%$ of the PGF $2 \alpha$ dose in the Bai Hui acupoint, T3 $=30 \%$ of the eCG dose in the Bai Hui acupoint and $100 \%$ of the intramuscular PGF $2 \alpha$ dose, T $4=30 \%$ of the dose of eCG and PGF $2 \alpha$ in the Bai Hui acupoint and T5 $=30 \%$ of the dose of eCG and PGF2 $\alpha$ in the false acupoint.

\section{Discussion}

A $100 \%$ estrus rate was obtained in all experimental groups except for the false acupoint group. This result demonstrates no loss of efficiency when PGF2 $\alpha$ and eCG doses were reduced by up to $30 \%$ in promoting actions on the hypothalamic-pituitary-ovarian axis, including probable regression of present luteal bodies, stimulation of gonadotrophin release, and follicular steroidogenesis, resulting in estrus synchronization 
and exteriorization. The results obtained in all groups are satisfactory and is within parameters recommended in the literature. Leite et al. (2006) have reported that a $66.6 \%$ estrus rate is considered satisfactory for caprine species. Souza et al. (2011), report that estrus detection is of great value for both artificial insemination and natural coverage. In addition, there is a positive correlation between estrus behavior and gestation rate when hormonal protocols are used for synchronization.

Other researchers have also tested reduced hormone doses applied at the Bai Hui acupoint in small ruminants, and reported good results for estrus induction. Maffili et al. (2006) tested protocols similar to those in the present study, using $60 \mathrm{mg}$ of medroxyprogesterone acetate, plus PGF $2 \alpha$ and eCG, and reported $100 \%$ rates of estrus in goats. Martinez et al. (2007) administered 20\% of the recommended dose of cloprostenol sodium at the Bai Hui acupoint in sheep, and efficiently induced estrus in $66.7 \%$ of animals. Similarly, Araújo (2016) reduced the recommended dose of eCG by $20 \%$, applied it at the Bai Hui acupoint, and induced estrus in $80 \%$ of the goats, similar to the induction rate in the control group, which received $100 \%$ of the dose by IM injection.

The interval between sponge removal and onset of estrus was similar among the groups, with an average of $49.72 \pm 8.93 \mathrm{~h}(\mathrm{p}>0.05)$. Traldi et al. (2007) report that estrus can occur in goats between 12 and $48 \mathrm{~h}$ after withdrawal of the progesterone source, which differs from the results obtained in the present study. Other authors have reported a smaller interval for estrus manifestation after sponge removal, using a higher dosage of eCG. Maffili et al. (2006), using 250 IU of eCG in goats, reported an interval between sponge removal and estrus initiation of $35.0 \pm 5.89$ h. Maia Júnior et al. (2009), also using $250 \mathrm{IU}$ of eCG, reported an average interval of $31.53 \pm 2.81 \mathrm{~h}$. Similarly, NavaTrujillo et al. (2010) reported an average of $32.54 \pm$ 3.00 h using 500 IU of eCG. Araújo (2016) reported an interval between sponge removal and estrus onset of $40.8 \pm 27.7 \mathrm{~h}$ when applying $60 \mathrm{IU}$ of eCG at the goats Bai Hui acupoint.

These results demonstrate that the dosage of eCG can influence the timing of estrus onset in goats, corroborating the observations of Guido et al. (2008) and Nava-Trujillo et al. (2010). According to these authors, the use of eCG stimulates initiation and synchronization of estrus in goats, and increasing the dose promotes earlier appearance of estrus. However, the fact that estrus occurred 3 $\mathrm{h}$ outside the recommended window in this study does not mean that the use of a lower dose of eCG is not feasible. Knowing the relationship between dosage and timing of onset of estrus should help establish the best time to perform IATF, avoiding low fertility rates, since ovulation will also occur a few hours later than expected, and viability of the oocyte is short-lived.

As the beginning of estrus after the sponge was withdrawn was delayed, the interval between removal of the sponge and the end of estrus was also longer. In the present study, this variable was equivalent $(p>0.05)$ among groups, with a mean of $76.8 \pm 13.0 \mathrm{~h}$ (Table 3 ). This differs from the average of $70.9 \mathrm{~h}$ between sponge removal and end of estrus reported by Souza et al. (2011), using 100 IU of eCG for each $10 \mathrm{~kg}$ of body weight. Our results also differ from those of Araújo (2016), who recorded a $68.2 \pm$ $38.5 \mathrm{~h}$ interval when applying $60 \mathrm{IU}$ of eCG at the Bai Hui acupoint in goats. Despite differences in the interval between sponge withdrawal and beginning/ end of estrus reported in the previous studies and in the present study, the duration of estrus $(27.1 \pm 11.2$ $\mathrm{h}$ ), is within physiological norms for the caprine species. According to Maia and Bezerra (2010) the norm ranges from 24 to $48 \mathrm{~h}$. Duration of estrus was similar among groups in this study $(p>0.05)$ (Table 3). Similar results were obtained by Pietroski et al. (2013), who reported an estrus duration of $29.4 \mathrm{~h}$ for Saanen goats.

In induction and estrus synchronization protocols, equine chorionic gonadotropin can raise 
estrogen levels, as it stimulates steroidogenesis and follicle growth in the ovary. Increased estrogen stimulates estrus behavior. Consequently, elevated estrogen levels may increase the duration of estrus (FONSECA et al., 2007). The results obtained in the present study suggest that application of eCG at the Bai Hui acupoint or at the false acupoint elevated estrogen to levels equivalent to those induced by a full dose (300 IU) administered by IM injection, and produced similar estrus duration, despite eCG dose reduction by $70 \%$.

A mean of $0.68 \pm 0.04 \mathrm{~cm}$ was obtained for the largest follicle in each group, corroborating data described by Cruz et al. (2008), who tested an 11day protocol using sponges impregnated with $45 \mathrm{mg}$ of fluorogestone acetate, followed by administration of $250 \mathrm{IU}$ of eCG in Saanen and Anglo Nubian goats, and obtained the largest follicle size of 0.71 $\mathrm{cm}$. Souza et al. (2011) tested effects of FSH instead of eCG on estrus behavior and follicular dynamics in dairy goats, and reported the size of the largest follicle to be $0.94 \mathrm{~cm}, 38 \%$ bigger than the one obtained in the present study. The authors attributed their result to the use of a long protocol, which can promote excessive growth and persistence of large dominant follicles.

The interval between sponge withdrawal and ovulation was similar among groups $(\mathrm{p}>0.05)$, with a mean of $78.28 \pm 10.82 \mathrm{~h}$ (Table 4 ), in agreement with Souza et al. (2011) who reported an average of $78.87 \mathrm{~h}$ for treatment with $100 \mathrm{IU}$ of eCG. Both of these intervals are longer than that described by Pietroski et al. (2013) who observed a $52.5 \mathrm{~h}$ interval between sponge withdrawal and ovulation using $200 \mathrm{IU}$ of eCG. The difference in results can be explained by the lower doses of eCG used in the present study, and that of Souza et al. (2011). This parameter is important for identification of the moment of ovulation, and to establish the best fixed time to proceed with artificial insemination.

The mean interval between the beginning of estrus and the occurrence of ovulation was $28.52 \pm$
$5.44 \mathrm{~h}$ (Table 4), similar to the mean interval of 28.8 $\mathrm{h}$ reported by Pietroski et al. (2013), using $200 \mathrm{IU}$ of eCG. These values are substantially lower than that found by Souza et al. (2011), who reported an average interval of $48.23 \mathrm{~h}$. The results obtained in the present study indicate that, although the interval between sponge withdrawal and onset of estrus was longer than in comparable studies, ovulation did not occur late, suggesting that neither reduction of the eCG dose, nor the Bai Hui route of application impaired ovulation. Ovulation occurred within the estrus phase, which was of normal duration for caprine species.

Application of a reduced dose of eCG via the Bai Hui acupoint did not influence the follicular growth rate $(\mathrm{p}>0.05)$. A mean of $0.86 \pm 0.29 \mathrm{~mm} /$ day (Table 4) was obtained for this variable lower than that found by Maffili et al. (2006), who, in testing a 5-day protocol with CIDRGTM, together with intramuscular application of $5 \mathrm{mg}$ of dinoprost (a synthetic analog of PGF2 $\alpha$ ), 1mg of estradiol cypionate, and $250 \mathrm{IU}$ of eCG, obtained an average follicular growth rate of $2.2 \pm 0.96 \mathrm{~mm} /$ day. Souza et al. (2011) using a 10-day protocol with MAP, $0.5 \mathrm{~mL}$ of cloprostenol (Prolise ${ }^{\mathrm{TM}}$ ), and $100 \mathrm{IU}$ of eCG for every $10 \mathrm{~kg}$ of body weight, obtained an intermediate mean follicular growth rate of $1.35 \pm$ $0.5 \mathrm{~mm} /$ day. Martínez-García et al. (2007) suggested that increased growth rates in some follicles occur after progesterone concentrations decrease in the blood. Plasma progesterone levels in the present study were determined 7 days after ovulation. This timing corresponds to initiation of diestrus in the luteal phase of the estrus cycle in goats, when the corpus luteum has formed and is producing and secreting progesterone at increasing levels, possibly reducing the rate of follicular growth.

As with follicular growth rate, mean number of ovulations was not influenced by the treatments $(\mathrm{p}>0.05)$. The average number of ovulations was $1.32 \pm 0.23$ (Table 4), suggesting that application of the $90 \mathrm{IU}$ reduced dose of eCG at the Bai Hui 
acupoint potentiated the effect of the drug. These results corroborate those of Souza et al. (2011), who reported an average of 1.5 ovulations for goats receiving $100 \mathrm{IU}$ of eCG intramuscularly; and Pietroski et al. (2013) who reported a mean of 1.6 for goats receiving $200 \mathrm{IU}$ of eCG, also by intramuscular injection.

The gestation rate in the present study was 75 $\pm 12.5 \%$ (Table 5 ) at 30 days after coverage and is within the expected range for caprine species. According to Fonseca et al. (2005), the gestation rate in goats can vary between $50 \%$ and $80 \%$ using natural mating. The gestation rate for the group that received reduced doses of PGF $2 \alpha$ and eCG at the $B a i$ $H u i$ acupoint (group four) was identical to that of the control group, in which the recommended dose of each hormone was administered intramuscularly. The group 4 gestation rate was higher than results described in the literature. Maia Júnior et al. (2009) applied progesterone implants for 5 days in goats, then administered $50 \mu \mathrm{g}$ of PGF $2 \alpha$ and $250 \mathrm{IU}$ of eCG upon removal of the implants, and obtained a $52.6 \%$ rate of gestation. Araújo (2016) also reported a lower gestation rate $(60 \%)$ than that observed in the present study when administering $60 \mathrm{IU}$ of eCG at the Bai Hui acupoint. These results suggest that the effect of the $90 \mathrm{IU}$ dose of eCG may have been potentiated by the use of the Bai Hui acupoint, which efficiently promoted better gestation rates.

Serum progesterone levels obtained on the 7th day after ovulation were similar among the treatment groups $(\mathrm{p}>0.05)$. The mean was 10.28 $\pm 1.65 \mathrm{ng} . \mathrm{mL}^{-1}$ (Table 5), suggesting presence of a functional corpus luteum, since, according to Bauernfeind and Holtz (1991), the cutoff level of progesterone to distinguish presence or absence of a functional corpus luteum is between 0.5 and 1.0 ng.mL ${ }^{-1}$. The result obtained in this study also corroborates Fredriksson et al. (1984), who reported plasma concentrations of $\mathrm{P}_{4}$ ranging from 5 to 10 $\mathrm{ng} / \mathrm{ml}$ during the period of corpus luteum activity, in the estrus cycle of goats (from 7th day to luteolysis).
In other studies, lower $\mathrm{P}_{4}$ concentrations than those obtained in this study have been observed. The values obtained by Léga et al. (2005), who collected blood near the same time point used in our study (7 days after ovulation detection), are between $5.04 \pm 4.35$ ng.mL $\mathrm{m}^{-1}$ on day 6 , and $7.16 \pm$ 7.14 ng. $\mathrm{mL}^{-1}$ on day 9 , for animals later diagnosed as pregnant. Also, Prosperi et al. (2006) reported an average of 5.99 ng. $\mathrm{mL}^{-1}$ of plasma progesterone at 8 days after ovulation in goats either untreated or treated with hCG. Our results demonstrate that reduced dosage eCG treatments were efficient in promoting formation of a functional corpus luteum, yielding adequate plasma concentrations of $\mathrm{P}_{4}$ for maintenance of gestation in goats.

The mean values for prolificity obtained in this study did not differ among the treatments ( $p$ $>0.05$ ). Values averaged $1.32 \pm 0.23$ (Table 5), which is within the range of 1.44 to 1.76 reported by Simplício (2008) for adult goats. The average number of births in the present study is similar to the averages reported in other studies, such as Araújo (2016), who obtained a mean of $1.5 \pm 0.5$ when applying $60 \mathrm{IU}$ of eCG at the Bai Hui acupoint in goats. Similarly, Sarmento et al. (2010) reported an average herd prolificity of 1.49 kids/female, when studying the prolificity history of dairy crossbred goats with natural mating and without the use of estrus synchronization protocols in the northeastern semi-arid region. Cardoso et al. (2018), using a protocol similar to the one used in this study, applied $30 \%$ of the recommended dose of eCG at the Hou Hai acupoint and obtained a prolificity of $1.50 \pm 0.55$ in goats.

The results obtained in this study, as evidenced by the rates of estrus induction, estrus duration, pregnancy rates, serum progesterone concentration, and prolificity, demonstrate the efficacy of using reduced hormonal doses in estrus synchronization protocols, and the potential benefits of other routes of drug administration, such as the Bai Hui acupoint, corroborating studies by Luna et al. (2006), which 
suggest that the use of reduced doses applied in acupoints produces an effect of similar duration and potency as that of the conventional dose.

The administration of $30 \%$ cloprostenol sodium $(39.75 \mu \mathrm{g})$ and eCG (90 IU) at the Bai Hui acupoint and false acupoint in estrus synchronization protocols in goats efficiently synchronized estrus and ovulation, and yielded satisfactory gestation rates and prolificity, with lower protocol costs. Because it is more practical, it is suggested that reduced doses be performed intramuscularly for this purpose, since the standard dose used for the species is clearly overestimated, as demonstrated in this study.

The research project was submitted to the evaluation of the ethics committee of animal research of the Universidade Federal do Recôncavo de Bahia and approved under case number 23007.0098 10/2011-28.

\section{References}

ALTMAN, S. Técnica de instrumentação. In: SCHOEN, A. M. (Ed.). Acupuntura veterinária: da arte antiga à moderna. 7. ed. São Paulo: ROCA, 2006. p. 91-108.

ARAÚJO, R. C. S. A. Farmacopuntura utilizando os acupontos Hou Hai e Bai Hui em protocolos de sincronização de estro em caprinos. 2016. Dissertação (Mestrado em Ciência Animal) - Universidade Federal do Recôncavo da Bahia, Cruz das Almas.

BALDASSARE, H. Reproducción asistida en la espécie caprina: inseminación artificial a clonación. Revista Brasileira Reprodução Animal, Belo Horizonte, v. 31, n. 2, p. 274-282, 2007.

BAUERNFEIND, M.; HOLTZ, W. Progesterone and estrogen levels in serum of cycling goats measured by enzyme immunoassay. Small Ruminant Research, Amsterdam, v. 6, n. 1-2, p. 95-102, 1991. DOI: 10.1016/0921-4488(91)90012-F

CARDOSO, R. C.; BARBOSA, L. P.; SOUZA, R. S.; FRANÇA, C. S.; RIBEIRO JUNIOR, M. D. M.; SANTANA, A. L. A.; JESUS, R. D. L.; SANTOS, R. S. Application of hormonal subdoses at acupoint Hou Hai in estrus synchronization protocols of goats. Semina: Ciências Agrárias, Londrina, v. 39, n. 3, p. 1135-1142, 2018. DOI: $10.5433 / 1679-0359.2018 v 39 n 3 p 1135$
CRUZ, J. F.; TEIXEIRA, D. I. A.; RONDINA, D.; FREITAS, V. J. F. Dinâmica folicular ovariana em cabras em anestro após tratamento progestágeno. Revista Brasileira de Saúde e Produção Animal, Salvador, v. 9, n. 4, p. 825-833, 2008.

FONSECA, J. F.; BRUSCHI, J. H.; SANTOS, I. C. C.; VIANA, J. H. M.; MAGALHÃES, A. C. M. Induction of estrus in non-lactating dairy goats with different estrous synchrony protocols. Animal Reproduction Science, Amsterdam, v. 85, n. 1-2, p. 117-124, 2005. DOI: 10.1016/j.anireprosci.2004.03.005

FONSECA, J. F.; SOUZA, J. M. G.; BRUSHI, J. H. Sincronização de estro e superovulação em ovinos e caprinos. In: SIMPÓSIO DE CAPRINOS E OVINOS DA EV-UfMG, 2., 2007, Belo Horizonte. Anais... Belo Horizonte: Editora CENEx, EV/UFMG, 2007. p. $167-$ 194.

FREDRIKSSON, G.; KINDAHL, H.; EDQVIST, L. E. Ketotetranor PGF metabolites, a suitable indicator for measuring prostaglandin release during the normal oestrus cycle and early pregnancy in the goat. Animal Reproduction Science, Amsterdam, v. 7, n. 6, p. 537-545, 1984. DOI: $10.1016 / 0378-4320(84) 90059-9$

GUIDO, S. I.; GUIDO, F. C. L.; NASCIMENTO FILHO, E. V.; FREITAS NETO, L. M.; ALVES, J. D. R.; EVÊNCIO NETO, J.; LIMA, P. F.; OLIVEIRA, M. A. L. Avaliação de protocolos hormonais para inseminar cabras em tempo fixo. Medicina Veterinária, Recife, v. 2, n. 3, p. 13-18, 2008.

KÜÇÜKASLAN, İ.; ASLAN, S.; AY, S. S.; KAYA, D.; FINDIK, M.; KAÇAR, C.; WOLLGARTEN, B.; BOLLWEIN, H. Investigation of the effects of acupuncture stimulation on the size and blood flow of corpus luteum and progesterone levels in dairy cows. Journal of the Faculty of Veterinary Medicine, Kafkas, v. 21, n. 6, p. 877-883, 2015.

LÉGA, E.; TONIOLlO, G. H.; FERRAUDOS, F. Concentração sérica de progesterona para diagnóstico precoce de gestação. Ciência Animal Brasileira, Goiânia, v. 6, n. 1, p. 35-40, 2005.

LEITE, P. A. G.; CARVALHO, G. R.; RODRIGUES, M. T.; RUAS, J. R. M.; AMORIM, E. A. M.; MAFFILI, V. V. Indução da ovulação em cabras, fora da estação reprodutiva, com LH e GnRH e com estro induzido por progestágenos. Arquivo Brasileiro de Medicina Veterinária e Zootecnia, Belo Horizonte, v. 58, n. 3, p. 360366, 2006. DOI: 10.1590/S0102-09352006000300012

LUNA, S. P. L.; ANGELI, A. L.; FERREIRA, C.; LETTRY, V.; SCOGNAMILLO-SZABÓ, M. Comparison of pharmacopuncture, aquapuncture and acepromazine 
for sedation of horses. eCAM Advance Access Published, v. 5, n. 3, p. 1-6, 2006.

MAFFILI, V. V.; TORRES, C. A. A.; BRUSCHI, J. H.; FONSECA, J. F.; VIANA, J. H. M. Indução de estro em cabras da raça Toggenburg com dois diferentes dispositivos intravaginais. Arquivo Brasileiro de Medicina Veterinária e Zootecnia, Belo Horizonte, v. 58, n. 3, p. 367-372, 2006.

MAIA JÚNIOR, A.; ARAÚJO, A. A. de; SALLES, M. G. F. Indução e sincronização do estro e da ovulação em cabras leiteiras saanen com uso de dispositivos vaginais associados ou não à eCG ou efeito macho. Acta Veterinaria Brasilica, Mossoró, v. 3, n. 4, p. 157-162, 2009. DOI: 10.21708/avb.2009.3.4.1439

MAIA, K. M.; BEZERRA, A. C. D. S. Controle do ciclo estral em caprinos: revisão. Acta Veterinaria Brasilica, Mossoró, v. 4, p. S14-S19, 2010. Suplemento.

MARTINEZ, A. C.; OLIVEIRA, F. S.; CADAMURO, V. A. H. Uso de baixa dose de cloprostenol sódico administrado pelo ponto Bai Hui de acunpuntura em ovelhas. Archives of Veterinary Science, Curitiba, v. 12, n. 4, p. 231-232, 2007.

MARTÍNEZ-GARCÍA, J. Á.; SÁNCHEZ-TORRES, M. T.; CORDERO, J. L.; MENDOZA, G. D.; GARCIABOJALIL, C. M.; GARCIA-WINDER, M. Ovarian follicular dynamics after cauterization of the dominant follicle in anoestrous ewes. Animal Reproduction Science, Amsterdam, v. 98, n. 3-4, p. 225-232, 2007. DOI: $10.1016 /$ j.anireprosci.2005.12.018

NAVA-TRUJILLO, H.; CHANGO-VILLASMIL， J.; FINOL-PARRA， G.; TORRES-RODRÍGUEZ, P.; CARRILLO-FERNÁNDEZ, F.; MALDONADOSUÁREZ, J.; GIL-HUERTA, L.; AKOURKI, A. Efecto de la dosis de eCG sobre la inducción del celo en cabras mestizas luego de un tratamiento corto con Medroxiprogesterona. Revista Cientifica, Maracaibo, v. 20, n. 2, p. 181-183, 2010.

PIETROSKI, A. C. C. A.; BRANDÃO, F. Z.; SOUZA, J. M. G. de; FONSECA, J. F. da. Short, medium or longterm hormonal treatments for induction of synchronized estrus and ovulation in Saanen goats during the nonbreeding season. Revista Brasileira de Zootecnia, Viçosa, MG, v. 42, n. 3, p. 168-173, 2013. DOI: 10.1590/ S1516-35982013000300004
PROSPERI, C. P.; TORRES, C. A. A.; GUIMARÃES, J. D.; BRUSCHI, J. H.; LEITE, P. A. G.; MAFFILI, V. V. Taxa de gestação em cabras Alpinas e Saanen tratadas com hCG no terceiro dia após o estro. Arquivo Brasileiro de Medicina Veterinária e Zootecnia, Belo Horizonte, v. 58 , n. 2 , p. $190-195$, 2006. DOI: 10.1590/S010209352006000200007

SARMENTO, J. L. R.; PIMENTA FILHO, E. C.; ABREU, U. G. P. de; RIBEIRO, M. N.; SOUSA, J. E. R. de. Prolificidade de caprinos mestiços leiteiros no semiárido nordestino. Revista Brasileira de Zootecnia, Viçosa, MG, v. 39, n. 7, p. 1471-1476, 2010.

SIMPLÍCIO, A. A. Estratégias de manejo reprodutivo como ferramenta para prolongar o período de oferta de carnes caprina e ovina no Brasil. Tecnologia e Ciência Agropecuária, João Pessoa, v. 2, n. 3, p. 29-39, 2008.

SOUZA, R. S.; BARBOSA, L. P.; AGUIAR, C. S.; FIGUEREDO JÚNIOR, J.; RIBEIRO, M. O.; MENDES, C. S.; ALMEIDA, V. F.; ARAÚJO, R. C. S. A.; PINHEIRO, A. M.; MARQUES, J. A. Sincronização da ovulação utilizando FSH em substituição à eCG em cabras. Arquivo Brasileiro de Medicina Veterinária e Zootecnia, Belo Horizonte, v. 63, n. 3, p. 753-756, 2011.

TEIXEIRA, I. A. M.; GOMES, R. A.; CASTAGNINO, D. S. Inovações tecnológicas na caprinocultura. Revista Brasileira de Saúde Produção Animal, Salvador, v. 14 , n. 1, p. $4-120,2013$. DOI: 10.1590/S151999402013000100012

TRALDI, A. de S.; LOUREIRO, M. F. P.; CAPEZZUTO, A.; MAZORRA, A. L. Métodos de controle da atividade reprodutiva em caprinos. Revista Brasileira de Reprodução Animal, Belo Horizonte, v. 31, n. 2, p. 254260, 2007.

URIBE-VELÁSQUEZ，L. F.; SOUZA， M. I. L.; OSORIO, J. H. Resposta ovariana de cabras submetidas a implantes de progesterona seguidos de aplicações de gonadotrofina coriônica equina. Revista Brasileira de Zootecnia, Viçosa, MG, v. 39, n. 6, p. 1214-1222, 2010. DOI: $10.1590 / \mathrm{S} 1516-35982010000600008$ 
